\title{
A new species and new combination in Clusiaceae-Calophylloideae from New Guinea
}

\author{
P.F. Stevens
}

\begin{abstract}
Stevens. P.F. (Harvard University Herbaria, 22 Divinity Avenue, Cambridge, Mass 02138, USA) 1993. A new species and new combination in Clusiaceae-Calophylloideae from New Guinea. Telopea 5(2): 359-361. A distinctive new species of Mammea, M. papyracea, known only from a single collection from the Morobe Province, Papua New Guinea, is described. Following the recent separation of Kayea and Mesua, a new combination, K. coriacea, is made; a recent collection of this species represents a range extension of $1500 \mathrm{~km}$.
\end{abstract}

\section{Introduction}

The new species described below and the new combination made are necessitated by the forthcoming publication of Volume 3 of the 'Handbooks of the Flora of Papua New Guinea'.

\section{Mammea}

It is with some hesitation that I describe a new species of Mammea since the genus is very poorly known throughout its Malesian range, with the exception of the seaside M. odorata (Raf.) Kostermans and the Bornean M. acuminata (Kostermans) Kostermans. However, in the course of monographing the genus, it became clear that the specimen that is described below as $M$. papyracea has so many distinctive features that it merits formal description.

Mammea papyracea P.F. Stevens, sp nov.

A speciebus aliis Mammeae foliis petiolis $5-10$ x c. $2.5 \mathrm{~mm}$, laminis basibus rotundatis vel subcordatis, venis utrinque haud prominentibus, venis submarginalibus 3-seriatis, venulis ultimis obscuris, et glandulis laticibus c. $3 \mathrm{~mm}$ distantibus, differt.

Type: Papua New Guinea: Morobe: Lae subdistrict, Buso, $30 \mathrm{ft}[9 \mathrm{~m}]$, H. Streimann et al., NGF 39414, 6/5/[19]69 (holo A; iso BO, CANB, K, L, LAE).

Tree c. $9 \mathrm{~m}$ tall, c. $7.5 \mathrm{~cm}$ d.b.h. Outer bark light brown, pustular, middle bark creamy brown; inner bark brown; latex white, turning yellow. Sapwood straw-coloured; heartwood reddish brown. Terminal bud conoid, 6-7.5 x 1.2-1.5 mm, apex of perulae narrowly cuneate; twigs slightly flattened, $2-3.4 \mathrm{~mm}$ across, drying striate when young, otherwise smooth, pale yellowish brown, with a transverse line at the node; innovations with c. 3 pairs of perulae within $2 \mathrm{~mm}$, another pair with an internode $5-20 \mathrm{~mm}$ long, and 1 or 2 pairs of expanded leaves with internodes $4.5-8 \mathrm{~cm}$ long. Petiole (3-)5-10 x c. $2.5 \mathrm{~mm}$, strongly concave above; lamina elliptic-oblong, 14-23 x 4.2-9 $\mathrm{cm}$, apex acuminate to almost rounded, acumen to $7 \mathrm{~mm}$ long, base broadly rounded to subcordate, margin narrowly recurved, texture thinly coriaceous, surface above smooth, below dull brown, slightly glaucous, midrib above slightly depressed at the base, becoming raised, $0.7-1.0 \mathrm{~mm}$ across at the midpoint of the blade, more or less 
sulcate especially in the bottom half, below raised, striate, secondary veins slightly raised on both surfaces, more prominent than other venation, 12-15 per side, $0.9-2.7$ $\mathrm{cm}$ apart, diverging from the midrib at $60-70^{\circ}$, joining submarginal vein $0.4-1.6 \mathrm{~cm}$ from the margin, additional submarginal veins c. 5 and c. $2 \mathrm{~mm}$ from the margin, intersecondary veins not reaching the submarginal vein, fine venation hierarchical, slightly raised on both surfaces, the finest venation almost invisible, areolae c. $1 \times 1$ $\mathrm{mm}$ (?), latex glands visible on the upper surface only, 2-4 mm apart. Inflorescences and flowers unknown. Pedicel (in fruit) $>1.4 \mathrm{~cm}$ long. Fruit (submature) spherical, c. $5 \times 5 \mathrm{~cm}$, apex rounded, surface drying broadly and irregularly wrinkled or not, also striate; pericarp to $3 \mathrm{~mm}$ thick; seed single, testa adnate to the pericarp, c. $0.5 \mathrm{~mm}$ thick, embryo with distinct cotyledons.

Mammea papyracea may be recognised by its relatively long and slender petioles and blades that are rounded to subcordate at the base - a unique combination in the genus. The blades have a distinctive, papyraceous texture, the finest venation is practically invisible (hence the uncertainty over the size of the areoles in the description), and the latex glands are relatively distant. The innovations have few perulae -4 or more pairs are much more common in non-Malagasy species - and only one or two pairs of expanded leaves. The last two characters might seem unsatisfactory, since one would think a priori that they would be correlated directly with the vigour of the plant from which the specimen was obtained, nevertheless, they show suprisingly little infraspecific variation in Mammea.

All these features clearly distinguish $M$. papyracea from $M$. novoguineensis (Kan. \& Hat.) Kostermans with which I had earlier confused it (Stevens 1974). The spherical fruits, with their very strong pericarp and thin testa, are also distinctive; fruits presumably of this species are associated with the type collection of M. cordata P. F. Stevens, which has banana-shaped fruits (cf. Stevens 1974: Fig. 1B, C).

Although the upper surface of the leaf is smooth, there are the same subepidermal fibers that are almost universal in the Malagasy-Indian-Malesian species of the genus; these fibers are absent from the African and American species, and also from the Australian M. touriga (White \& Francis) L.S. Smith.

\section{Kayea}

Although Kayea Wall. has until recently been included in Mesua L. (Stevens 1986, cf. Kostermans 1969), the two may readily be distinguished by their growth pattern, morphology, anatomy, and probably also xanthone chemistry; there is no evidence that the two form a monophyletic group (Stevens, pers. obs.). This necessitates a new combination for the erstwhile Mesua coriacea.

Kayea coriacea (P. F. Stevens) P.F. Stevens, comb. nov.

Basionym: Mesua coriacea P.F. Stevens, Austral. J. Bot. 22: 422. f. 4 (1974).

Type: Papua New Guinea: Western: Agu River Branch of the Middle Fly River, 25' [8 m], R. Pullen 7426, 2 Oct. 1967 (holo LAE; iso A, BRI, CANB, K, L).

A specimen ( $L A E 70901$ ) probably of this species that is just past flowering has recently been collected from Sudest Island in the Louisiade Archipelago. This represents a range extension of some $1500 \mathrm{~km}$; $K$. coriacea was hitherto known only from three collections made in the Western Province of Papua New Guinea. However, there is disconcerting variability in leaf surface, venation, and ovule number in the species as currently circumscribed, and more collections are urgently needed. 


\section{Acknowledgements}

I am very grateful to the directors of the herbaria mentioned for permission to examine the specimens held in their collections.

\section{References}

Kostermans, A.J.G.H. (1969) Kayea Wall. and Mesua L. (Guttiferae). Reinwardtia 7: 425-431.

Stevens, P.F. (1974). Mammea L. and Mesua L. (Guttiferae) in Papuasia. Australian Journal of Botany 22: 413-423.

Stevens, P.F. (1986). Mesua ferrea became $M$. nagassarium but has to be called $M$. ferrea again (Guttiferae). Taxon 35: 352-354.

Manuscript received 26 October 1992

Manuscript accepted 10 February 1993 